\title{
Modeling and control of actuators and co-surge in turbocharged engines
}

\author{
Andreas Thomasson
}

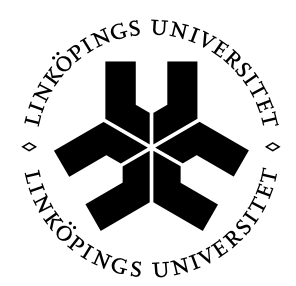

\section{Linköpings universitet INSTITUTE OF TECHNOLOGY}

Department of Electrical Engineering

Linköping University

SE-581 83 Linköping, Sweden

Linköping 2014 
Linköping studies in science and technology. Dissertations, No. 1590

Modeling and control of actuators and co-surge in turbocharged engines Andreas Thomasson ISBN 978-91-7519-355-7

ISSN 0345-7524

(C) 2014 Andreas Thomasson, unless otherwise noted. All rights reserved.

Andreas Thomasson

andreast@isy.liu.se

ww. vehicular.isy.liu.se

Division of Vehicular Systems

Department of Electrical Engineering

Linköping University

SE-581 83 Linköping

Sweden

Paper 1 is reproduced here with permission from IFP Energies nouvelles Paper 2 is reproduced here with permission from IFAC

Paper 3 is reproduced here with permission from Elsevier

Paper 4 is reproduced here with permission from IFAC

The cover: Photo of an electronic throttle, a pneumatic actuator, and a measurement of mass flows during co-surge, illustrating the main topics of the thesis.

Typeset with $\operatorname{AT}_{\mathrm{E}} \mathrm{X} 2 \varepsilon$

Printed by LiU-Tryck, Linköping, Sweden 2014 


\section{Abstract}

The torque response of the engine is important for the driving experience of a vehicle. In spark ignited engines, torque is proportional to the air flow into the cylinders. Controlling torque therefore implies controlling air flow. In modern turbocharged engines, the driver commands are interpreted by an electronic control unit that controls the engine through electromechanical and pneumatic actuators. Air flow to the intake manifold is controlled by an electronic throttle, and a wastegate controls the energy to the turbine, affecting boost pressure and air flow. These actuators and their dynamics affect the torque response and a lot of time is put into calibration of controllers for these actuators. By modeling and understanding the actuator behavior this dynamics can be compensated for, leaving a reduced control problem, which can shorten the calibration time.

Electronic throttle servo control is the first problem studied. By constructing a control oriented model for the throttle servo and inverting that model, the resulting controller becomes two static compensators for friction and limp-home nonlinearities, together with a PD-controller. A gain-scheduled I-part is added for robustness to handle model errors. The sensitivity to model errors is studied and a method for tuning the controller is presented. The performance has been evaluated in simulation, in test vehicle, and in a throttle control benchmark.

A model for a pneumatic wastegate actuator and solenoid control valve, used for boost pressure control, is presented. The actuator dynamics is shown to be important for the transient boost pressure response. The model is incorporated in a mean value engine model and shown to give accurate description of the transient response. A tuning method for the feedback (PID) part of a boost controller is proposed, based on step responses in wastegate control signal. Together with static feedforward the controller is shown to achieve the desired boost pressure response. Submodels for an advanced boost control system consisting of several vacuum actuators, solenoid valves, a vacuum tank and a vacuum pump are developed. The submodels and integrated system are evaluated on a two stage series sequential turbo system, and control with system voltage disturbance rejection is demonstrated on an engine in a test cell.

Turbocharged V-type engines often have two parallel turbochargers, each powered by one bank of cylinders. When the two air paths are connected before the throttle an unwanted oscillation can occur. When the compressors operate close to the surge line and a disturbance alters the mass flow balance, the compressors can begin to alternately go into surge, this is called co-surge. Measurements on co-surge in parallel turbocharged engines are presented and analyzed. A mean value engine model, augmented with a Moore-Greitzer compressor model to handle surge, is shown to capture the co-surge behavior. A sensitivity analysis shows which model parameters have the largest influence of the phenomena. The compressor operation in the map during co-surge is studied, and the alternating compressor speeds are shown to have a major impact on the continuing oscillation. Based on the analysis, detection methods and a controller are proposed, these detect co-surge and control the turbo speeds to match during co-surge. The controller is evaluated both in simulation and on a test vehicle in a vehicle dynamometer, showing that co-surge can be detected and the oscillations quelled. 


\section{Populärvetenskaplig sammanfattning}

Momentsvaret från motorn är viktigt för körkänslan i en bil. För bensinmotorer är momentet proportionellt mot luftmassflödet till cylindrarna, att styra momentet är därför nära kopplat till att styra luftflödet. I moderna motorer översätts förarens gaspådrag till en momentbegäran av motorns styrstyrsystem som sedan skickar styrsignaler till flertalet elektromekaniska och pneumatiska ställdon. Ett av dessa är det elektroniskt styrda trottelspjället som reglerar luftflödet till insugsröret. Spjället är kopplat till en elmotor och för att få önskat luftmassflöde krävs därför precision och tillförlitlighet i styrningen av denna. I turboladdade motorer utvinns energi ur avgaserna av en turbin som driver en kompressor med uppgiften att öka laddtrycket och därmed luftmassflödet till motorn på höga laster. Turbon styrs vanligtvis med en wastegate på avgassidan som kan leda avgaser förbi turbinen. Wastegaten är kopplad till ett pneumatiskt ställdon där trycket regleras av en elektroniskt styrd ventil. Dynamiken hos dessa komponenter påverkar motorns respons, och styrsystemet måste kalibreras för att hantera detta vilket kan vara mycket tidskrävande.

I avhandlingen utvecklas reglerorienterade modeller av motorställdon för att underlätta kalibrering av motorns styrsystem. En regulator för motorns elektroniska trottelspjäll föreslås. Regulatorn består av en olinjär statisk framkoppling och linjär återkoppling som fås naturligt genom att modellera och förenkla systemet. Vidare presenteras en metod för att parametersätta regulatorns olika delar. Komponentmodeller till ett system för styrning av avancerade turbokonfigurationer tas fram. Systemet består av pneumatiska styrdon, elektroniskt styrda ventiler, en vakuum tank och en vakuum pump. Modellerna är konstruerade för att vara enkla att identifiera från mätdata och ha en sund fysikalisk tolkning för att kunna hantera varierande omgivningsförhållanden. Flera applikationer diskuteras, bland annat kompensering för varierande batterispänning, vilket testas på en motor med ett seriesekvensiellt dubbelturbosystem i en motortestcell.

Ett turbokoncept för $\mathrm{V}$-motorer är att använda två parallella turboaggregat, kopplade till ett gemensamt insugsrör. I denna konfiguration kan det uppstå ett oönskat oscillativt fenomen då kompressorerna jobbar vid hög tryckkvot och lågt massflöde. Om balansen mellan aggregaten störs kan en turbo ta över och producera mer flöde, medans flödet genom den andra turbon reverserar. Den turbo som inte producerar flöde kommer att accelerera och flödet vänder tillbaka. Det aggregatet kommer då producera mer flöde och man får en oscillation i massflöde mellan de två turboaggregaten, detta fenomen kallas co-surge. I avhandlingen presenteras och analyseras mätningar av co-surge och en modell som kan användas för att simulera co-surge utvecklas. Modellen används för att analysera systemet, undersöka vilka faktorer som har störst inverkan på oscillationen och för att utveckla detektions och reglerstrategier. Analysen visar att turboaggregatens varierande varvtal under co-surge är en betydande orsak till oscillationen. Detektionsmetoder och reglerstrategi för att snabbt återhämta systemet från co-surge tas fram. Regulatorn öppnar trotteln för att kompensera för det minskade luftmassflödet och flyttar temporärt kompressorns arbetspunkt, samtidigt som den styr turbovarvtalen mot varandra. Regulatorn utvärderas i testbil på chassidynamometer, och experimenten visar att den snabbt för tillbaka systemet till en stabil arbetspunkt. 


\section{Acknowledgment}

Five years and seventy five days is a long time, at least from my perspective. During that time there are lots of people that have contributed in one way or another, and when summarized, have made this thesis possible.

First of all I would like to thank my supervisor Lars Eriksson for all guidance and support along the way, without you I would not even have started this journey. I want to thank Lars Nielsen for letting me join Vehicular Systems and all co-workers in the group for providing a fruitful research environment and enjoyable discussions during coffee breaks. Special thanks to Oskar Leufvén both as research partner and for supervising the undergraduate project "RATT", which turned my interest to automotive control systems to begin with.

Then I would like to thank my friends, especially Henrik Svensson, Marcus Wallenberg, Jonas Sjöqvist and Ulf Winberg. For everything from lunches and bowling, to Sweden Rock and the Netherlands, but mostly for always being good company.

I want to thank my father Sten for always being supportive, I will always look up to you, and my mother Eva for always believing that I could manage everything I wanted.

Finally I would like to express my love for Elisabet who has been by my side for more than nine years, you make me happy. 


\section{Contents}

1 Introduction $\quad \mathbf{3}$

1.1 Summary and main contributions of the papers included in the thesis 5

1.2 Other publications by the author . . . . . . . . . . 6

1.3 Future work . . . . . . . . . . . . . . . . . . 7

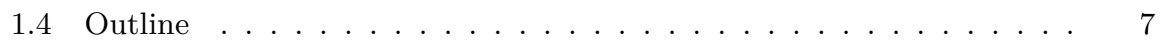

2 Background on boost control and its actuators $\quad 9$

2.1 The electronic throttle . . . . . . . . . . . . . . . . . 9

2.2 The pneumatic actuation system . . . . . . . . . . . . . . . 11

2.3 Engine modeling and boost control . . . . . . . . . . . . . . . 13

$\begin{array}{lll}3 & \text { Experimental setups } & \mathbf{1 7}\end{array}$

3.1 The engine laboratory . . . . . . . . . . . . . . . 17

3.2 The vehicle propulsion laboratory . . . . . . . . . . . . . . . . . 18

3.3 Sensor equipment and installation . . . . . . . . . . . . 18

$\begin{array}{ll}\text { References } & 21\end{array}$

$\begin{array}{ll}\text { Papers } & 29\end{array}$

1 Model-Based Throttle Control using Static Compensators and Pole $\begin{array}{ll}\text { Placement } & 31\end{array}$

1 Control oriented throttle model . . . . . . . . . . . . . . . . 33

2 Controller structure . . . . . . . . . . . . . . . 36

3 Identification and controller tuning . . . . . . . . . . . . . . . . . 40

4 Simulation results on TC benchmark model . . . . . . . . . . . . 45

$5 \quad$ Experimental results . . . . . . . . . . . . . . . . . . 50 
6 The throttle control benchmark . . . . . . . . . . . . . . . 51

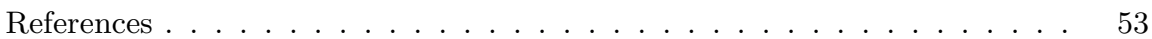

2 Wastegate Actuator Modeling and Model-Based Boost Pressure Control $\quad \mathbf{5 5}$

$1 \quad$ Introduction . . . . . . . . . . . . . . . . . . 57

2 Wastegate actuator modeling . . . . . . . . . . . . . . . 59

3 Boost pressure controller . . . . . . . . . . . . . . . 65

4 Controller tuning and results . . . . . . . . . . . . . . . 69

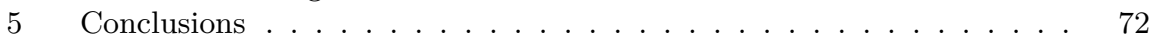

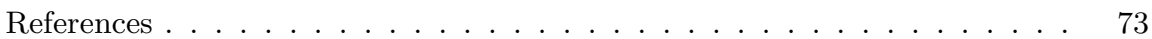

3 Modeling and validation of a boost pressure actuation system, for a $\begin{array}{lr}\text { series sequentially turbocharged SI engine } & \mathbf{7 5}\end{array}$

1 Introduction . . . . . . . . . . . . . . . . . . 77

2 Experimental setup . . . . . . . . . . . . . . . . . . 79

3 Actuator modeling . . . . . . . . . . . . . . . . . . . 81

4 Vacuum tank and pump model . . . . . . . . . . . . . . . . . . 90

5 Model applications . . . . . . . . . . . . . . . . . . . 92

6 Summary and conclusions . . . . . . . . . . . . . . . . . 96

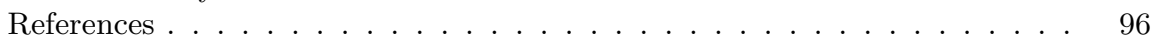

A Nomenclature . . . . . . . . . . . . . . . . . . 99

4 Modeling and Control of Co-Surge in Bi-Turbo Engines 101

1 Introduction . . . . . . . . . . . . . . . . . . . . . 103

2 Co-surge . . . . . . . . . . . . . . . . . . 103

3 Engine model . . . . . . . . . . . . . . . . . . . . . . 105

4 Compressor model . . . . . . . . . . . . . . . . . . . 106

5 Analysis of surge properties . . . . . . . . . . . . . . . . . . 108

$6 \quad$ Pipe dynamics investigation . . . . . . . . . . . . . . . . . . . . . . 109

7 Control . . . . . . . . . . . . . . . . . . . . . 111

8 Conclusions . . . . . . . . . . . . . . . . . . . . 113

References . . . . . . . . . . . . . . . . . . . 115

A Nomenclature . . . . . . . . . . . . . . . . 116

5 Co-Surge in Bi-Turbo Engines - Measurements, Analysis and Con$\begin{array}{lr}\text { trol } & 117\end{array}$

$1 \quad$ Introduction . . . . . . . . . . . . . . . . . . . . . . . . 119

2 Test setup . . . . . . . . . . . . . . . . . . . . . . . 120

3 Surge and co-surge . . . . . . . . . . . . . . . . . . . . . . 121

4 Control oriented engine model . . . . . . . . . . . . . . . . . 123

5 Co-surge analysis . . . . . . . . . . . . . . . . . . . 131

6 Detection . . . . . . . . . . . . . . . . . . 133

$7 \quad$ Co-surge control . . . . . . . . . . . . . . . . . . . . 136

8 Conclusions . . . . . . . . . . . . . . . . . . . . . . . 143

References . . . . . . . . . . . . . . . . . . . . . 143

A Nomenclature . . . . . . . . . . . . . . . . . . . . . . 145 


\section{Introduction}





\section{Introduction}

The modern Internal Combustion (IC) engine is a result of continuous development during the past century up until today. The combination of increasing performance and reliability, together with low cost and high availability of fuel, has lead to the point where the IC engine is, without competition, still the most widely used power source for vehicle propulsion. Even if fossil fuels will be phased out eventually, the introduction of renewable fuels gives good reason to believe that the IC engine will continue to be of major importance for a foreseeable future.

The basic working principles of the IC engine is simple. A mixture of air and fuel is compressed by a piston inside a cylinder and ignited. The mixture burns which increases temperature and pressure inside the cylinder, the piston is pushed down and work is extracted. The burnt gases are then replaced by fresh air fuel mixture and the cycle is repeated. A more in-depth description of basic internal combustion engine operation will not be given in this thesis, and the interested reader is referred to e.g. Heywood (1988); Stone (2012).

A combination of increasingly strict emission legalization and a demand for lower fuel consumption, with equal or improved performance, has pushed the development to more complex engine systems. A part of this development is the movement toward more drive-by-wire systems, and one important step was the introduction of the electronic throttle controlled by the Engine Control Unit (ECU). By removing the direct connection between the gas pedal position and the throttle angle, the torque response of the engine can be shaped by the control system design. It also allows the ECU to more accurately predict the air flow to the engine and controlling the air fuel ratio, improving emissions, fuel economy and driveability (Tudor, 1993; Strieb and Bischof, 1996). Today all modern car engines use electronic throttles, which in addition to the benefits above, allows the control system to coordinate the throttle command with other systems that affects torque. 
Another concept that has become common practice is downsizing and turbocharging, where large naturally aspirated engines are replaced by smaller turbocharged ones (Emmenthal et al., 1979; Watson and Janota, 1982). The turbocharger increases the intake pressure which increases the air flow into the cylinders. Since torque is proportional to the amount of fuel burnt in the cylinder, which is limited by the amount of available air, this enables the turbocharged engine to produce more torque and power compared to a naturally aspirated engine of the same size. For a given power requirement the engine can therefore be reduced, improving fuel economy by lowering friction and pumping losses (Guzzella et al., 2000). To gain further benefits from downsizing more advance turbo concepts are being developed (Petitjean et al., 2004). There are systems with both series sequential (Chasse et al., 2008; Galindo et al., 2009c), and parallel sequential turbochargers (Borila, 1986; Galindo et al., 2009a).

The turbo is powered by energy in the exhaust gas, and the power generated can be controlled by letting part of the exhaust gas bypass the turbine through a wastegate. The wastegate is usually operated by a pneumatic actuator, and the pressure in the actuator is controlled by a solenoid valve connected to the ECU. The addition of these systems to the engine increases the flexibility and degrees of freedom for the air charge management, since in addition to the electronic throttle, also the wastegates have a large influence on the air flow to the cylinders. To be able to both minimize fuel consumption and have desired transient response of the engine, control of these actuators needs to be coordinated. This coordination could not be expected to be handled by the driver and a modern engine is therefore a drive-by-wire system, where the driver commands are interpreted by the ECU that controls engine operation through electromechanical and pneumatic actuators.

The behavior of these actuators affect both static and transient engine response, and to get the desired behavior a lot of time is required for calibration. The traditional approach has been to store controller parameters in look-up tables to handle different operating points and surrounding conditions. This approach has a clear downside when the degrees of freedom increase, since the number of parameters increase exponentially with the number of inputs. To reduce this burden, model based approaches are getting more attention. By exchanging maps for model based relationships, the number of parameters can be reduced and the calibration time shortened. This requires models with good accuracy over their operating region, and that are easily identified from measurements. The models should handle varying surrounding conditions and behave in a sensible way outside their nominal region to not cause problems for the control system. This is a strength of physically based models, where the surrounding condition can be explicitly included, thereby reducing the need for additional calibration. 


\subsection{Summary and main contributions of the pa- pers included in the thesis}

This section summarizes the five papers included in the thesis and highlights the main contributions.

Paper 1 (Thomasson and Eriksson, 2011b) contributes with a model based controller for an electronic throttle servo that consists of two static compensators and a modified PID-controller. The paper includes an automatic tuning method for the controller parameters and a sensitivity and robustness investigation with respect to the limp-home and friction nonlinearities. The controller is relatively simple, with a less complex friction model than usually proposed in the literature, and a PID-controller with fewer degrees of freedom. It was also the best performing controller of the participants in the Throttle Control Benchmark, described in Zito et al. (2009).

The main contribution of Paper 2 (Thomasson et al., 2009) is a control oriented model for a pneumatic wastegate actuator and air control solenoid. The wastegate model consists of three submodels; the actuator pressure, the static position, and an additional position dynamics. The dynamics of the actuator turns out to be important for the transient response, in particular the actuator characteristics is responsible for an overshoot in boost pressure for step changes in actuator input. The model is incorporated in a complete Mean Value Engine Model (MVEM), that is used to study the system and develop a tuning method for the boost pressure feedback controller, a gain scheduled PID. Together with a static feedforward, the controller achieves desired transient response in boost pressure.

In Paper 3 (Thomasson et al., 2013b) an actuation system for an advanced turbocharging system is studied. It incorporates a vacuum pump and a vacuum tank, pneumatic actuators and pulse width modulation controlled solenoid valves. The paper contributes with component models that are easily identified from measured data. Their physical interpretation enables them to handle varying surrounding conditions. The models are evaluated on a two stage series sequential turbo system with three actuators having different characteristics. Several applications are presented, including a nonlinear compensator for voltage disturbance rejection.

Paper 4 (Thomasson and Eriksson, 2011a) presents experimental data on co-surge in a bi-turbocharged engine, where the two parallel turbos alternately goes into surge. An engine model able to capture the co-surge phenomena is presented. The model consists of a MVEM augmented with a Moore-Greitzer compressor model to handle surge. A sensitivity study with respect to parameter variations and their effect on the co-surge behavior is performed. It is concluded that the parameters with largest influence on the behavior are the size of the volumes after the compressor, the compressor inertia, and the pressure drop from the zero slope point at the surge line to zero mass flow in the compressor speed lines. The effect of adding momentum conservation to the pipes before and after the compressor is studied but the resulting behavior is quantitatively similar. There is also a first investigation of detection and control of co-surge. 
A deeper analysis of co-surge is presented in Paper 5 (Thomasson and Eriksson, 2014). The paper includes more precise co-surge measurements from a test vehicle in a chassis dynamometer, used in both model validation and control evaluation. The driving force behind the co-surge oscillation is studied and the diverging turbo speeds during the surge cycle is shown to be of importance. The paper proposes a detection algorithm suitable for either mass flow, pressure or turbo speed sensors. The paper also contributes with a controller that quells the co-surge oscillation by forcing the turbo speeds together during the surge cycle, thereby ensuring a more balanced recovery point and reducing the risk of continuing oscillation.

\subsection{Other publications by the author}

This section summarizes research publications that the author has been involved in, but that is not included in the thesis.

A Andreas Thomasson, Lars Eriksson, Tobias Lindell, James Peyton Jones, Jill Spelina, and Jesse Frey, Tuning and experimental evaluation of a likelihood-based engine knock controller, 2013, 52nd IEEE Conference on Decision and Control, Florence, Italy (Thomasson et al., 2013a)

B Andreas Thomasson and Lars Eriksson, Co-Surge Detection and Control for Bi-Turbo Engines with Experimental Evaluation, 2013, Advances in Automotive Control, Tokyo, Japan (Thomasson and Eriksson, 2013)

C Lars Eriksson, Tobias Lindell, Oskar Leufvén, and Andreas Thomasson, Scalable Component-Based Modeling for Optimizing Engines with Supercharging, E-Boost and Turbocompound Concepts, 2012, SAE International Journal of Engines (Eriksson et al., 2012b)

D Lars Eriksson, Tobias Lindell, Oskar Leufvén, and Andreas Thomasson, Scalable Component-Based Modeling for Optimizing Engines with Supercharging, E-Boost and Turbocompound Concepts, Technical paper 2012-01-0713, 2012, SAE World Congress, Detroit, USA (Eriksson et al., 2012a)

E Ivan Criscuolo, Oskar Leufvén, Andreas Thomasson, and Lars Eriksson, Model-based boost pressure control with system voltage disturbance rejection, 2011, IFAC World Congress, Milano, Italy (Criscuolo et al., 2011)

F Andreas Thomasson and Lars Eriksson, Model-Based Throttle Control using Static Compensators and IMC based PID-Design, 2009, IFAC Workshop on Engine and Powertrain Control, Simulation and Modeling, Paris, France (Thomasson and Eriksson, 2009)

G Andreas Thomasson, Wastegate Actuator Modeling and Tuning of a PID Controller for Boost Pressure Control, 2009, Masters Thesis, LiTH-ISYEX-09/4232-SE, Linköping University (Thomasson, 2009) 
The author's contributions to these journal and conference publications are indicated by the author list, where the first author is the main contributor to a publication. In the knock controller evaluation $\mathbf{A}$, the author did the implementation on the engine control system, a large part of the engine tests and the experimental part of the paper. In the co-surge control experimental evaluation in $\mathbf{B}$, the author has developed the detection and control algorithms, done the implementation on the test vehicle and run the experiments. This work was preliminary to Paper 5 in the thesis (Thomasson and Eriksson, 2014). For publications $\mathbf{C}$ and $\mathbf{D}$ the author was contributing to a literature survey of charging concepts. For publication $\mathbf{E}$ the author was part of the weekly meetings and discussions about the projects development, problems and possible solutions. For publication $\mathbf{F}$ the author has done the majority of the work, controller development, implementation on the control system and experimental evaluation. This work was preliminary to Paper 1 in the thesis (Thomasson and Eriksson, 2011b). Publication G is the author's Masters Thesis that contains preliminary work to Paper 2 (Thomasson et al., 2009).

\subsection{Future work}

This section gives a very brief outlook on possible extensions to the work in the thesis that has been thought about, but not received the deserved attention.

The tuning of the throttle controller in Paper 1 uses offline calibration together with a limp-home calibration during start up. An interesting continuation would be to investigate if the process curve can be accurately estimated during normal operation, for example during a driving cycle.

One goal of the actuation system modeling in Paper 3 is the use in boost control. The final puzzle for closing the loop with model based control would be an accurate model for the relation between wastegate position and effective flow area. Given a total mass flow, turbo speed and desired turbine power, the correct wastegate position could then be calculated for accurate feedforward.

The focus in Papers 4-5 has been modeling, detection and recovery from co-surge. A challenging topic would be prediction of when co-surge is about to begin, and to develop a controller to stop the onset of the oscillation.

\subsection{Outline}

The goal of the three introductory chapters is to introduce the topics covered in the thesis, place the contributions of the thesis in the research field and describe the experimental setups used during the thesis work.

The first two sections of Chapter 2 introduces the electronic throttle and pressure actuators, the topics of Papers 1-3. The systems are described and related research results on modeling, simulation and control are presented. Section 2.3 begins with an introduction to engine modeling with mean value engine models, used frequently during the thesis work. Applications of MVEM in control design are then presented followed by a short introduction to surge modeling and control, with focus on research on vehicle applications. Chapter 3 
presents two of the experimental setups used in the thesis with information on sensors, their characteristics and installation. The appended papers then cover the thesis' contributions to electronic throttle control, pneumatic actuator modeling with application to boost control, and co-surge modeling and control. 


\section{Background on boost control and its actuators}

This chapter gives an introduction to engine modeling, boost control and two of its most important actuators, the electronic throttle that controls air flow into the intake manifold, and the pneumatic actuator that is the most common actuator for the wastegate that controls the energy to the turbine in the turbocharger. The basic structure of the actuators are described and an overview of previously published research and the relation to the thesis is presented.

\subsection{The electronic throttle}

Benefits of replacing the conventional throttle, mechanically connected to the gas pedal by a wire, with an electronically controlled throttle valve was pointed out already in the early 90s. Improvements in both emissions, fuel economy and driveability were shown (Tudor, 1993; Strieb and Bischof, 1996). Advantages also include easier interaction with other systems such as cruise control, traction slip control and idle speed control (Mausner and Pfalzgraf, 1990; Huber et al., 1991). The electronic throttle is a relatively inexpensive DC servomotor that provides position control of the throttle plate and thus controls the air flow to the intake manifold (Pavković and Deur, 2011). To enable feedback control and provide robustness, the throttle position is measured by two potentiometers for redundancy (Jurgen, 1994). The DC motor is controlled by a Pulse Width Modulated (PWM) signal, the most common approach for DC servo control due to the low power requirement, small size and low cost (Alciatore and Histand, 2003). An example of an electronic throttle and a sketch of the components of the electronic throttle control are shown in Fig. 2.1. The throttle housing contains the DC-motor, gearbox (omitted in the figure), throttle plate, position sensor and return spring. The controller and chopper are integrated in the ECU. 

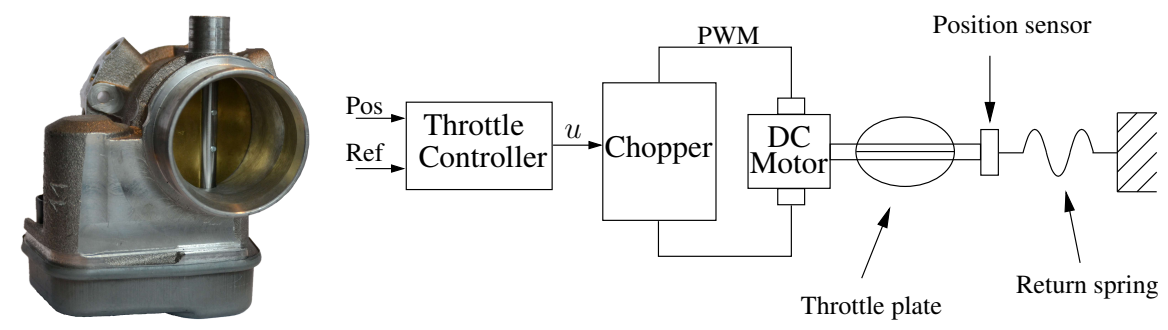

Figure 2.1: Left: Example of an electronic throttle body. The housing contains a DC-motor, gearbox, throttle plate, position sensor and return spring. Right: A sketch of the electronic throttle and position controller.

\subsubsection{Throttle modeling and control}

The servo control problem for the electronic throttle is complicated by two strong nonlinearities, the torque from the return spring and friction. Since accurate control of this servo is required for precision in the air flow control, modeling, simulation and control of this servo has been an active research topic since the late $90 \mathrm{~s}$. The models can usually be divided into three parts, linear terms for the electric motor, a nonlinear model for friction torque, and a nonlinear model for the return spring torque, which is usually piecewise linear. Different models used in the literature then mainly differ in the complexity of these submodels, especially the friction model. For a good overview of the friction models mentioned in this section, see Olsson et al. (1998). In addition, a model for the torque from the air flow on the throttle plate can be included, but is usually omitted or considered an unknown disturbance.

A simulation model of an electronic throttle is presented in Scattolini et al. (1997). Friction effects are modeled by Coulomb friction and stiction effect. Parameter identification are discussed, based on the process static curve and a step response in duty cycle. The Coulomb friction model is also used in Eriksson and Nielsen (2000), but the authors extend it with viscous friction and proposes a control strategy consisting of a PI and friction compensator. An observer is also designed with the main goal of estimating the throttle angular velocity, that is used in the friction compensator. A very similar strategy is used in Al-Assidi et al. (2006) that uses Coulomb friction and an velocity observer to provide friction compensation, together with a PID controller. Also in Özgüner et al. (2001) Coulomb friction and a piecewise linear spring force is used to model the nonlinear effects, but a discrete time sliding-mode controller and observer is designed. A similar model is used in Barić et al. (2005) to implement a neuralnetwork based sliding mode controller, and in Pan et al. (2008) that designs a variable-structure control using backstepping and a sliding-mode observer.

A more advanced friction model is adopted in Canudas de Wit et al. (2001) that uses a dynamic LuGre friction model (Canudas de Wit et al., 1999), and adaptive pulse control to overcome friction for small displacement operation. In Deur et al. (2003b, 2004) it is shown that the LuGre model cannot capture throttle friction dynamics accurately and a hybrid friction model is proposed, 
consisting of a Dahl dynamic submodel for the presliding regime and the generalized Striebeck static submodel for the sliding regime. The paper also presents an electronic throttle control strategy based on a PID controller and compensators for friction and limp-home. This controller is also extended with an auto-tuner and a self-tuning strategy in Deur et al. (2003a) and Pavković et al. (2003, 2006). A comprehensive treatment of modeling and control of the electronic throttle together with this controller, auto-tuning and self-tuning strategies and applications is found in Pavkovic and Deur (2011).

The performance of state estimators for the electronic throttle is studied in Vašak et al. (2003). An Extended Kalman Filter (EKF) and an Unscented Kalman Filter (UKF) are compared, and the UKF is shown to behave better for this application. This filter is used in Vašak et al. $(2006,2007)$ that applies optimal control theory and full state feedback to the electronic throttle control problem. Full state feedback is also used in Loh et al. (2007), where input-output state feedback linearization together with pole-placement are utilized. Control schemes that use a reference model directly in the controller to adapt model parameters online have also been suggested for the throttle control problem. In Jiang and Kitchen (2010), a PID controller together with model reference adaptive control (see e.g. Åström, 1983) is utilized. An adaptive linear quadratic controller is presented in di Bernardo et al. (2010).

The controller presented in Paper 1 combines previous ideas and adds new contributions. It consists of two nonlinear static feedforward compensators for friction and limp-home effects, and in contrast to Deur et al. (2004) they are active simultaneously. Friction compensation is based on Coulomb friction only as in Eriksson and Nielsen (2000); Al-Assidi et al. (2006), but estimation of the throttle plate angular velocity is avoided by always acting in the direction to reduce the tracking error. This approximately linearizes the system and then PID control is applied. The I-part is gain scheduled with high gain for small errors to ensure fast response and robustness to model errors for small reference changes, which are typically problematic. The controller is relatively simple, easy to tune with the provided tuning method, and has proved satisfactory performance. It was also the best performing controller in the throttle control benchmark at the 2009 IFAC Workshop on Engine and Powertrain Control, Simulation and Modeling (Delarue and Tona, 2011).

\subsection{The pneumatic actuation system}

Pneumatic actuators are used in modern internal combustion engines to control different systems, many that affect boost pressure such as wastegate (WG) valves, bypass (BP) valves, exhaust gas recirculation (EGR) valves, variable geometry turbine (VGT) position (Moraal et al., 1999; Galindo et al., 2009b). The pressure in these actuators are usually controlled by the ECU through PWM solenoid valves, connected to a vacuum reservoir or boost pressure. An example of a pressure actuator and a sketch of the principal system is shown in Fig. 2.2. The pressure in the actuator will be in the range $\left[p_{1}, p_{2}\right]$ depending on the duty-cycle of the PWM signal. The pressure in the actuator results in a 

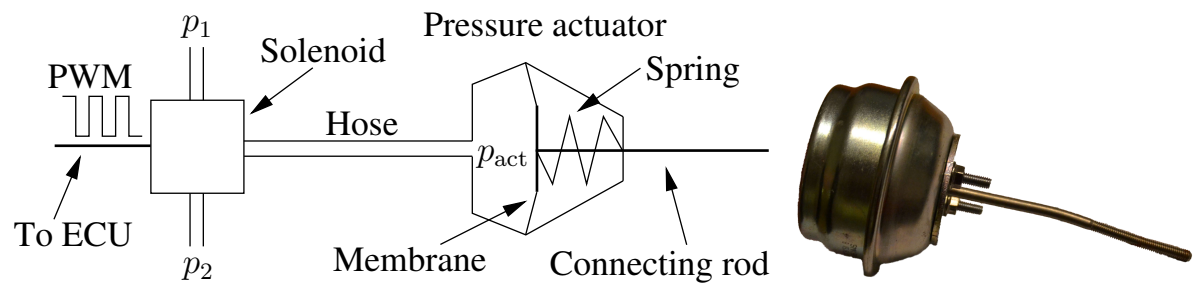

Figure 2.2: Left: A sketch of a pressure actuator connected to a solenoid. The pressure in the actuator, $p_{\text {act }}$ is controlled in the range $\left[p_{1}, p_{2}\right]$ by varying the duty-cycle of the PWM signal from the ECU. The pressures $p_{1}$ and $p_{2}$ can be connected to either a vacuum reservoir, boost pressure or ambient pressure.

Right: En example of a pressure actuator used to control a wastegate.

force on the membrane that transfers to the connecting rod, that is attached to the control target. The system could then include more components such as a vacuum pump, reservoirs, several actuators and valves.

\subsubsection{Modeling and control of pneumatic actuators}

Models for pneumatic systems with varying levels of detail have been proposed in the literature. In Moraal et al. (1999) modeling and identification of a control valves and pressure actuator for a VGT is presented. Isothermal control volumes with fixed size are used to model the pneumatic part of the actuator and the vacuum reservoir. Mass flows to and from the actuator are modeled with compressible flow equations and effective areas that depend on control signal and actuator pressure. A mass-spring-damper system is used to describe the actuator mechanics but no friction forces are considered. A very similar model for EGR valve control is studied in Kotwicki and Russell (1998), but adiabatic control volumes are used and compared with isothermal ones. The difference is shown to be very small.

A slightly more advance model is presented in Galindo et al. (2009b) for a vacuum system used for controlling a two-stage turbocharged engine. In this paper the effective area that governs the mass flow through the pressure control valves are dependent on the actual core position inside the solenoid valve instead of directly on the control signal. The core movement is modeled with a massspring-damper system, where the magnetic force depends directly on the PWM signal. More detailed models for the magnetic force inside the solenoid valves can be found in Szente and Vad (2001), that specifically studies simulation of the solenoid valve position. The paper by Galindo et al. (2009b) also compares 1D modeling of the pipes with using 0D models. No advantage of using 1D models for this application is found, the two models behave almost identically with lower computational burden for the 0D models. Friction models for pressure actuators are investigated in Mehmood et al. (2010, 2011), where the vacuum system for a VGT actuator is modeled. This is motivated by hysteresis in the relation between actuator pressure and position. The aerodynamic force affecting the actuator from the VGT is also investigated. Friction in pneumatic actuators had 
previously been used in pneumatic brake systems in e.g. Acarman et al. (2001). Another interesting result is found in Håkansson and Johansson (2007), where a state space model for a system consisting of a two solenoid valves and a pressure actuator is developed. The model includes electrical, magnetic, mechanical and flow submodels, and has a total of 9 states. PID and fuzzy control is applied, but satisfactory results are not obtained without adding position feedforward. With feedforward, only $\mathrm{P}$-control is required for desired performance.

Position control of pneumatic actuators have otherwise mostly been concerned with pneumatic cylinders where each side of the piston is connected to a separate control valve. In van Varseveld and Bone (1997), a nonlinear transformation between control signal and PWM duty-cycle is suggested to get a more linear velocity response. PID control and position feedforward is then applied. In Wang et al. (1999) acceleration feedback, PID control and a nonlinear compensator is used to track a velocity reference. Approximate feedback linearization is proposed in Xiang and Wikander (2004) to provide accurate position control. The linearization is made on a block-level, requiring only that specific blocks are invertible or approximately invertible. Force control of pneumatic cylinders are considered in Richer and Hurmuzulu (1999), where a nonlinear sliding mode controller is designed. The closely related pressure control problem is studied in Wang et al. (1999), where an LQG self-tuning controller is proposed.

The model presented in Paper 3, in this thesis, uses zero dimensional isothermal control volumes, which is sufficient for good accuracy according to results in Galindo et al. (2009b) and Kotwicki and Russell (1998). An opportunity for model reduction has been identified by observing that the solenoid valve acts as a controller for the pressure difference, shown also in Paper 2, and that the pressure respond approximately as a first order system. In contrast to previous publications, the need to identify the effective area of the valve is removed and the mass flow out of the tank can be calculated based on the pressure change in the actuator. Leakage flow through the valves, which usually is omitted, has also been modeled. Additionally the effect of different supply voltage is investigated and how the control signal can be modified to compensate for this during modeling and control design is shown.

\subsection{Engine modeling and boost control}

The use of models for simulation and development of engine controls is becoming increasingly important as the complexity of engine systems increase. Mean Value Engine Models (MVEM) offer good accuracy for low computational cost, and can be used to evaluate new control ideas cost effectively before implementation in a vehicle. They are widely used in industry and academia, and are both utilized and developed in Papers 2, 4 and 5 in this thesis.

The development of MVEM started in the 70s but the term was coined in the late $80 \mathrm{~s}$ and thereafter there has been a significant amount of research. In Hendricks (1989); Hendricks and Vesterholm (1992), mean value engine models are analyzed in both time and frequency domain. The models are shown to have good predicting capability in a large part of the engine operating region. 
A model of a spark ignited (SI) engines is presented in Hendricks and Sorenson (1990), and Jensen et al. (1991) develops a model for a small turbocharged diesel engine. The SI engine has three states, engine speed and pressure in the intake and exhaust manifold. The turbocharged engine also has turbo speed as a state. The SI engine is claimed to have an accuracy of $\pm 2 \%$ for most variables over the whole operating region. The validity of MVEM during transient operation is the topic of Chevalier et al. (2000) that concludes that the models perform well, but that isothermal control volumes give inaccurate air density during tip-in and tip-out. This is remedied in e.g. Müller et al. (1998); Eriksson et al. (2002b), where temperature states are added together with more components, such as intercooler and air filter. The publications by Moraal and Kolmanovsky (1999) and Sorenson et al. (2005) are concerned with turbocharger modeling suitable for MVEM. Both use relations between the dimensionless parameters for flow, $\Phi$, and energy, $\Psi$, to model compressor mass flow and efficiency. Another model that directly parameterize compressor speed lines and can handle both the surge and choke region of the compressor is presented in Leufvén and Eriksson (2013).

Along with development of MVEM, engine control based on these models has developed. An observer for the fuel film in the intake is developed in Hendricks et al. (1992) and used to improve air-fuel ratio control. In Eriksson et al. (2002a) it is shown that for fuel optimal operation of turbocharged SI engines, the wastegate should be fully open when no boost is needed, and for boosted operation the throttle should be fully opened and the intake pressure controlled by the wastegate. The use of MVEM in diesel engine control is found for example in Guzzella and Amstutz (1998) and Jankovic et al. (1998). In Eriksson (2007) the focus is on a component based modeling methodology for MVEM and several applications on control is presented. Publications on model based boost control, where the MVEM equations are used for model based feed forward and feedback linearization, include e.g. Müller (2008); Moulin et al. (2008); Moulin and Chauvin (2011). Coordinated throttle and wastegate control for improved transient response is treated in Kranik et al. (2005) and Gorzelic et al. (2012). A thorough treatment of engine modeling and control with MVEM is also found in Eriksson and Nielsen (2014). The actuator models developed in Papers 2-3 easily fit into the MVEM structure where they can be used to improve model accuracy and aid in the control design.

\subsubsection{Surge modeling and control}

Compressor surge is a well known mass flow instability phenomena that can occur when the pressure ratio over the compressor gets too large compared to the mass flow. Surge can be categorized in at least four different types: mild surge, classical surge, modified surge and deep surge (de Jager, 1995; Willems and de Jager, 1999). Among those only deep surge has reversed flow, and for co-surge studied in Papers 4-5, it is shown that reversed flow occurs.

A well known model to describe compressor surge is the Moore-Greitzer model (Greitzer, 1976, 1981), originally developed for axial flow compressors but shown to work also for centrifugal compressors in Hansen et al. (1981). A larger survey of modeling and control of surge is given in de Jager (1995), and a rich 
treatment is also found in Gravdahl (1998). Most research has been done on axial flow turbo machinery with gas turbines, but there are few studies on automotive size turbos, where most utilize the Moore-Greitzer model, e.g. Ammann et al. (2001); Leufvén and Eriksson (2008). Resent studies on surge in automotive applications combine the Moore-Greitzer model with 1D gas-dynamic model for the pipes around the compressor (Galindo et al., 2008, 2011). Studies on surge in parallel turbo systems are scarcer. Although the phenomena is mentioned already in Watson and Janota (1982), it has not received much research attention. Papers 4-5 in this thesis contribute to this area with studies on modeling and control of surge in a parallel turbo configuration for automotive applications. 


\section{3}

\section{Experimental setups}

This chapter describes two of the experimental setups used for measurements in the thesis, the engine laboratory (used in Papers 1-3), and the vehicle propulsion laboratory (used in Paper 5), both located at Vehicular Systems, Linköping University. A few measurements in Paper 2 and the measurements in Paper 4 have been done on a test track, for more information on these, see the respective papers. The chapter also gives a description of the external sensors used, i.e. non ECU.

\subsection{The engine laboratory}

The engine laboratory at Vehicular System consists of one test cell with two engine test stands. The engines of each test stand are connected to individual Schenck Dynas3-LI250 electric dynamometers from 2002 (rated speed of $10 \mathrm{krpm}$, rated power of $250 \mathrm{~kW}$, and rated torque of $480 \mathrm{Nm}$ ). The measurements in Papers 1-3 in this thesis mainly originate from one of the engines, but with two different turbo installations. The engine is a GM LNF engine, a 21 , four cylinder, spark ignited petrol engine, with dual variable cam phasing.

The first installation has a single twin-scroll turbo, BW K04-2277, and is rated at $260 \mathrm{hp}, 350 \mathrm{Nm}$. The wastegate for the turbine is actuated by overpressure controlled by a solenoid valve connected to boost pressure. The second installation uses a series sequential two-stage turbo system extended with actively controlled high pressure stage compressor by-pass, BW K04$2270+$ BW KP35-1574. Both wastegates and the compressor bypass are actuated by underpressure, controlled by solenoid valves connected to a vacuum tank. The measurements for the development of the actuator model in Paper 2 was performed on the first installation. The last measurement in Paper 2 
and all measurements in Paper 3 are performed on the second installation. Measurements on the electronic throttle for Paper 1 has been performed on both, but the throttle did not change between the installations.

The control system consists of a dSpace MicroAutoBox (MABx) and a RapidPro (RP) architecture. The code for the system is generated from a large Simulink model that is compiled using Real Time Workshop, and then executed on the MABx. Interaction with the control system is handled by the dSpace program ControlDesk running on the lab computer, that has also been used for the measurements.

\subsection{The vehicle propulsion laboratory}

For the measurements in Paper 5 the test vehicle is mounted in a chassis dynamometer. The system used is Rototest Energy 230 4WD, which consist of four mobile electric dynamometer units, power electronics and control system. In this application only two dynamometers have been used mounted to the two driven wheels of the test vehicle. The system has been used in constant speed mode where the dynamometers keep the desired speed of the vehicle as long as the required torque is within the limitations of the system. In the speed range 0-1000 rpm the limit for each axle is $1180 \mathrm{Nm}$ continuous toque and $2200 \mathrm{Nm}$ momentarily. Above that speed the system is limited by $124 \mathrm{~kW}$ continuous power and $230 \mathrm{~kW}$ momentarily per axle. For more information on the chassis dynamometer installation, functionality and performance, see Öberg et al. (2013). The measurement and control system used in these measurements is the same as in the engine lab, that was described in the previous section.

\subsection{Sensor equipment and installation}

In this section, the sensors used for measurements during the thesis are presented, with some installation details main characteristics. A description of the sensor operation on a more detailed level with the underlying physics is outside the scope of this thesis, and the interested reader is refereed to e.g. Westbrook and Turner (1994); Lindahl and Sandqvist (1996); Fraden (2010).

\subsubsection{Pressure}

To measure actuator pressure in Paper 2 a production manifold pressure sensor (part number 9132374) with a range of $25-175 \mathrm{kPa}$ absolute pressure was used. The sensor was connected to the hose between the pressure control valve and the actuator by a $\mathrm{T}$ coupling and a $50 \mathrm{~cm}$ long hose, $d=6 \mathrm{~mm}$. In Paper 3 the actuator pressures are measured by sensors from Kistler, of either the 4260series $(4260 \mathrm{~A} 50,340 \mathrm{kPa}$ and $4260 \mathrm{~A} 75,500 \mathrm{kPa}$, piezoresistive absolute pressure sensors, $0.05 \%$ Full Scale (FS) accuracy, 0.1\% FS stability per year, $3 \times$ FS proof pressure, $f_{\max }=2 \mathrm{kHz}$ ) or the 4295 -series $(4295 \mathrm{~A} 2$ and $4295 \mathrm{~A} 2 \mathrm{~V}, 200 \mathrm{kPa}$ absolute pressure sensors). The pressure sensors where connected between the pressure control valves and the actuators by $\mathrm{T}$ couplings and $50-100 \mathrm{~cm}$ long 
hoses, with diameter $d=6 \mathrm{~mm}$. The Kistler sensors are also used to measure all pressures in Paper 5 with the exception of the intake manifold pressure, that is measured by the standard production sensor and received from the CAN bus. The hoses connecting the measurement point and the sensors for those measurements are $1.5-3 \mathrm{~m}, d=6 \mathrm{~mm}$. A short time delay is expected due to the pipe length. The pressure will propagate with the speed of sound through the pipe, which for this pipe diameter is almost the same as the velocity of sound in free air, see for example Vance (1932); Iemoto and Watanabe (2004); Bajsić et al. (2007). This translates to a maximum delay of less than $10 \mathrm{~ms}$ for $3 \mathrm{~m}$ of pipe, which is the sampling time of the measurements in Paper 5.

\subsubsection{Mass flow}

For mass flow measurements in Paper 4 and Paper 5, three mass airflow (MAF) sensors of hot film type are used. The total flow is measured with a Bosch sensor (part number 0280128055 ) placed $10 \mathrm{~cm}$ after the air filter, $30 \mathrm{~cm}$ before the air path is divided. The two other, that measure the flow in each path, are Hitachi sensors (part number 12788131 / AFH60M-18). They are placed $10 \mathrm{~cm}$ after the division of the air path, approximately $80 \mathrm{~cm}$ before the compressors. Hot film MAF sensors are fast sensors with time constants of around $10 \mathrm{~ms}$ (Westbrook and Turner, 1994).

\subsubsection{Turbo speed}

Turbo speeds in Paper 5 are measured with Acam PicoTurn-BM V6, rotational speed measurement system for turbochargers. The system has a range of 200$400000 \mathrm{rpm}$ and has been used with digital output giving one pulse per revolution of the turbocharger, with a $50 \%$ duty cycle. The specified frequency precision is $0.009 \%$ of full scale.

\subsubsection{Position}

The wastegate position in Paper 2 and the bypass position in Paper 3 is measured with a Duncan 9615 linear position sensor, range $0-38 \mathrm{~mm}$, linearity $\pm 2 \%, 135^{\circ} \mathrm{C}$ max temperature. The wastegate positions for Paper 3 are measured with Gill Blade 25 non-contact position sensors, range $0-25 \mathrm{~mm}$, range accuracy $\pm 0.1 \mathrm{~mm}, 125^{\circ} \mathrm{C} \max$ temperature. Measurement of throttle position is covered in Section 2.1. 



\section{References}

Tankut Acarman, Umit Ozguner, Cem Hatipoglu, and Anne-Marie Igusky. Pneumatic Brake System Modeling for System Analysis. SAE Trans. J. of Commercial Vehicles, V109-2, September 2001.

Salem Al-Assidi, Jens Breitinger, and Nathan Murphy. Model-Based Friction and Limp Home Compensation In Electronic Throttle Control. Electronic Engine Controls, SP-2003, April 2006.

D. G. Alciatore and M. B. Histand. Mechatronics and measurement systems. McGraw-Hill, 2nd edition, 2003.

M. Ammann, N. P. Fekete, A. Amstutz, and L. Guzzella. Control-Oriented Modeling of a Turbocharged Common-Rail Diesel Engine. In Proc. of the Int. Conference on Control and Diagnostics in Automotive Applications, 2001.

Ivan Bajsić, Jože Kutin, and Tomaž Žagar. Response time of a pressure measurement system with a connecting tube. Instrumentation Science and Technology, 36:399-409, 2007.

Miroslav Barić, Ivan Petrović, and Nedjeljko Perić. Neural network-based sliding mode control of electronic throttle. Engineering Applications of Artificial Intelligence, 18(8):951-961, June 2005.

Yurij G. Borila. A Sequential Turbocharging Method for Highly-Rated Truck Diesel Engines. In SAE World Congr., Techn. Paper 860074, February 1986.

C. Canudas de Wit, H. Olsson, and K. J. Åström. A New Model for Control of Systems with Friction. IEEE Trans. on Automatic Control, 40(3):419-425, 1999 . 
Carlos Canudas de Wit, Ilya Kolmanovsky, and Jing Sun. Adaptive Pulse Control of Electronic Throttle. In Proc. of the American Control Conference, June 2001.

A. Chasse, P. Moulin, A. Albrecht, L. Fontvielle, A. Guinois, and L. Doléac. Double Stage Turbocharger Control Strategies Development. SAE Int. J. of Engines, 1(1):636-646, 2008.

Alain Chevalier, Martin Müller, and Elbert Hendricks. On the Validity of Mean Value Engine Models During Transient Operation. In SAE World Congr., Techn. Paper 2000-01-1261, March 2000.

Ivan Criscuolo, Oskar Leufvén, Andreas Thomasson, and Lars Eriksson. Modelbased boost pressure control with system voltage disturbance rejection. In Proc. of the IFAC World Congr., pages 5058-5063, August 2011.

Bram de Jager. Rotating stall and surge control: A survey. In Proc. of the IEEE Conference on Decision and Control, volume 2, pages 1857-1862, December 1995.

Claude Delarue and Paolino Tona. Éditorial. Oil $\&$ Gas Science and Technology - Rev. IFP, 66(4):541-547, 2011. doi: http://dx.doi.org/10.2516/ogst/2011149.

Joško Deur, Danijel Pavković, Martin Janszand, and Nedjeljko Perić. Automatic Tuning of Electronic Throttle Control Strategy. In Mediterranean Conference on Control and Automation, 2003a.

Joško Deur, Danijel Pavković, Nedjeljko Perić, and Martin Jansz. An Electronic Throttle Control Strategy Including Compensation of Friction and Limp-Home Effects. In Proc of the IEEE Int. Electric Machines and Drives Conference, volume 1, pages 200-206, June 2003b.

Joško Deur, Danijel Pavković, Nedjeljko Perić, Martin Jansz, and Davor Hrovat. An Electronic Throttle Control Strategy Including Compensation of Friction and Limp-Home Effects. IEEE Trans. on Industry Applications, 40(3):821-834, 2004.

Mario di Bernardo, Alessandro di Gaeta, Umberto Montanaro, and Stefani Santini. Synthesis and Experimental Validation of the Novel LQ-NEMCSI Adaptive Strategy on an Electronic Throttle Valve. IEEE Trans. on Control Systems Technology, 18(6):1325-1337, November 2010.

K.-D. Emmenthal, G. Hagermann, and W.-H. Hucho. Turbocharging small displacement spark ignited engines for improved fuel economy. In SAE World Congr., Techn. Paper 790311, February 1979.

Lars Eriksson. Modeling and Control of Turbocharged SI and DI Engines. Oil \& Gas Science and Technology - Rev. IFP, 62(4):523-538, 2007.

Lars Eriksson and Lars Nielsen. Non-linear Model-Based Throttle Control. Electronic Engine Controls, SP-1500:47-51, March 2000. 
Lars Eriksson and Lars Nielsen. Modeling and Control of Engines and Drivelines. John Wiley \& Sons, 2014.

Lars Eriksson, Simon Frei, Christopher Onder, and Lino Guzzella. Control and Optimization of Turbo Charged Spark Ignited Engines. In Proc. of the IFAC World Congr., Barcelona, Spain, July 2002a.

Lars Eriksson, Lars Nielsen, Jan Brugård, Johan Bergström, Fredrik Pettersson, and Per Andersson. Modeling of a turbocharged SI engine. Annual Reviews in Control, 26(1):129-137, October 2002b.

Lars Eriksson, Tobias Lindell, Oskar Leufvén, and Andreas Thomasson. Scalable Component-Based Modeling for Optimizing Engines with Supercharging, EBoost and Turbocompound Concepts. In SAE World Congr., Techn. Paper 2012-01-0713, April 2012a.

Lars Eriksson, Tobias Lindell, Oskar Leufvén, and Andreas Thomasson. Scalable Component-Based Modeling for Optimizing Engines with Supercharging, EBoost and Turbocompound Concepts. SAE Int. J. of Engines, 5(2):579-595, May 2012b.

Jacob Fraden. Handbook of Modern Sensors: Physics, Designs, and Applications. Springer, 4 edition, 2010.

J. Galindo, J.R. Serrano, H. Climent, and A. Tiseira. Experiments and modelling of surge in small centrifugal compressor for automotive engines. Experimental Thermal and Fluid Science, 32(3):818-826, 2008.

J. Galindo, H. Climent, C. Guardiola, and J. Domenech. Strategies for improving the mode transition in a sequential parallel turbocharged automotive diesel engine. Int. J. of Automotive Technology, 10(2):141-149, 2009a.

J. Galindo, H. Climent, C. Guardiola, and J. Doménech. Modeling the Vacuum Circuit of a Pneumatic Valve System. J. of Dynamic Systems, Measurement and Control, 131(3), May 2009b.

J. Galindo, H. Climent, C. Guardiola, and A. Tiseira. Assessment of a sequentially turbocharged diesel engine on real-life driving cycles. Int. J. of Vehicle Design, 49(1/2/3):214-234, 2009c.

Jose Galindo, Francisco Arnau, Andres Tiseira, Ricardo Lang, Hamid Lahjaily, and Thomas Gimenes. Measurement and Modeling of Compressor Surge on Engine Test Bench for Different Intake Line Configurations. In SAE World Congr., Techn. Paper 2011-01-0370, April 2011.

Patrick Gorzelic, Erik Hellström, Anna Stefanopoulou, Li Jiang, and Srinath Gopinath. A Coordinated Approach for Throttle and Wastegate Control in Turbocharged Spark Ignition Engines. In Proc of the Chinese Control and Decition Conference, pages 1524-1529, May 2012. 
Jan Tommy Gravdahl. Modeling and Control of Surge and Rotating Stall in Compressors. PhD thesis, Norweigan University of Science and Technology, 1998.

E.M. Greitzer. Surge and rotating stall in axial flow compressors-Part I: Theoretical compression system model. J. of Engineering for Power, 98(2):190-198, April 1976.

E.M. Greitzer. The Stability of Pumping Systems. J. of Fluids Engineering, 103 (1):193-242, June 1981.

L. Guzzella, U. Wenger, and R. Martin. IC-Engine Downsizing and PressureWave Supercharging for Fuel Economy. SAE World Congr., March 2000.

Lino Guzzella and Alois Amstutz. Control of Diesel Engines. Control Systems, 18(5):53-71, 1998.

K.E. Hansen, P. Jørgensen, and P.S. Larsen. Experimental and Theoretical Study of Surge in a Small Centrifugal Compressor. J. of Fluids Engineering, 103(3):391-395, 1981.

Elbert Hendricks. The Analysis of Mean Value Engine Models. In SAE World Congr., Techn. Paper 890563, February 1989.

Elbert Hendricks and Spencer C. Sorenson. Mean value modelling of spark ignition engines. SAE Trans. J. of Engines, 99(3):1359-1373, 1990.

Elbert Hendricks and Thomas Vesterholm. The Analysis of Mean Value SI Engine Models. In SAE World Congr., Techn. Paper 920682, February 1992.

Elbert Hendricks, Thomas Vesterholm, and Spenser C. Sorenson. Nonlinear, closed loop, SI engine control observers. In SAE World Congr., Techn. Paper 920237, February 1992.

John B. Heywood. Internal Combustion Engine Fundamentals. McGraw-Hill series in mechanical engineering. McGraw-Hill, 1988. ISBN 0-07-100499-8.

Klas Håkansson and Mikael Johansson. Modeling and Control of an ElectroPneumatic Actuator System Using On/Off Valves. Master's thesis, Linköpings University, SE-581 83 Linköping, 2007.

Werner Huber, Bernd Lieberoth-Leden, Wolfgang Maisch, and Andreas Reppich. New Approaches to Electronic Throttle Control. In SAE World Congr., Techn. Paper 910085, February 1991.

$\mathrm{Yu}$ Iemoto and Yoshiaki Watanabe. Measurements of Phase Velocity of a Sound Wave Propagating in a Tube in Low Frequency Region. Japanse J. of Applied Physics, 43(1):401-402, 2004.

Mrdjan Jankovic, Miroslava Jankovic, and Ilya Kolmonovsky. Robust nonlinear controller for turbocharged diesel engines. In Proc. of the IFAC Symposium on Advances in Automotive Control,, pages 1389-1394, June 1998. 
J.-P. Jensen, A. F. Kristensen, S. C. Sorenson, N. Houbak, and E. Hendricks. Mean Value Modeling of a Small Turbocharged Diesel Engine. In SAE World Congr., Techn. Paper 910070, February 1991.

Shugang Jiang and Michael H. Smith James Kitchen. Automatic Tuning of Two-Degree-of-Freedom PID Control for Engine Electronic Throttle System. Engine Control and Calibration, SP-2285, April 2010.

Ronald Jurgen. Automotive Electronics Handbook. McGraw-Hill, 1994.

Allan J. Kotwicki and John Russell. Vacuum EGR Valve Actuator Model. New Techniques in SI and Diesel Engine Modeling, SP-1366, 1998.

Amey Y. Kranik, Julia H. Buckland, and Jim S. Freudenberg. Electronic Throttle and Wastegate Control for Turbocharged Gasoline Engines. In Proc. of the American Control Conference, volume 7, pages 4434-4439, June 2005.

Oskar Leufvén and Lars Eriksson. Time to surge concept and surge control for acceleration performance. In Proc. of the IFAC World Congr., pages 2063-2068, Seoul, Korea, July 2008.

Oskar Leufvén and Lars Eriksson. A Surge and Choke Capable Compressor Flow Model - Validation and Extrapolation Capability. Control Engineering Practice, 21(12):1871-1883, 2013.

Per Erik Lindahl and William Sandqvist. Mätgivare, mätning av mekaniska storheter och temperatur. Studentlitteratur, 1996.

R. N. K. Loh, T. Pornthanomwong, J. S. Pyko, A. Lee, and M. N. Karsiti. Modeling, Parameters Identification, and Control of an Electronic Throttle Control (ETC) System. In Proc of the IEEE Int. Conference on Intelligent and Advanced Systems, pages 1029-1035, November 2007.

Eberhard S. Mausner and Manfred Pfalzgraf. The VDO Modular Throttle Body Concept for Electronic Engine Control. In SAE World Congr., Techn. Paper 900782, February 1990.

A. Mehmood, S. Laghrouche, and M. El Bagdouri. Nonlinear Modeling of the VNT Pneumatic Actuator with Aero-dynamic Force. In Proc. of the IFAC Symposium on Advances in Automotive Control,, July 2010.

A. Mehmood, S. Laghrouche, and M. El Bagdouri. Modeling identification and simulation of pneumatic actuator for VGT system. Sensors and Actuators A: Physical, 165(2):367-378, 2011.

Paul Moraal and Ilya Kolmanovsky. Turbocharger Modeling for Automotive Control Applications. In SAE World Congr., Techn. Paper 1999-01-0908, March 1999.

P.E. Moraal, I.V. Kolmanovsky, and M-J. van Nieuwstadt. Modeling and Identification of a Current to Vacuum Transducer and VNT actuator. In Proc. of the IEEE/ASME Int. Conference on Advanced Intelligent Mechatronics, Atlanta, USA, September 1999. 
P. Moulin, J. Chauvin, and B. Youssef. Modelling and Control of the Air System of a Turbocharged Gasoline Engine. In Proc. of the IFAC World Congr., pages 8487-8494, July 2008.

Philippe Moulin and Jonathan Chauvin. Modeling and control of the air system of a turbocharged gasoline engine. Control Engineering Practice, 19(3):287-297, 2011.

Martin Müller. Estimation and Control of Turbocharged Engines. In SAE World Congr., Techn. Paper 2008-01-1013, April 2008.

Martin Müller, ELbert Hendricks, and Spencer C. Sorenson. Mean Value Modelling of Turbocharged Spark Ignition Engines. Modeling of SI and Diesel Engines, SP-1330, 1998.

Per Öberg, Peter Nyberg, and Lars Nielsen. A New Chassis Dynamometer Laboratory for Vehicle Research. SAE Int. J. Passeng. Cars - Electron. Electr. Syst., 6(1):152-161, May 2013.

H. Olsson, K.J. Åström, C. Canudas de Wit, M. Gäfvert, and P. Lischinsky. Friction Models and Friction Compensation. European J. of Control, 4(3): 176-195, 1998.

Ümit Özgüner, Sulgi Hong, and Yaodong Pan. Discrete-time Sliding Mode Control of Electronic Throttle Valve. In Proc. of the IEEE Conference on Decision and Control, December 2001.

Yaodang Pan, Ümit Özgüner, and Oğuz Hasan Dağci. Variable-Structure Control of Electronic Throttle Valve. IEEE Trans. on Industrial Electronics, 55(11): 3899-3907, 2008.

Danijel Pavković and Joško Deur. Modeling and Control of Electronic Throttle Drive. LAP LAMBERT Academic Publishing, 2011. ISBN 978-3-8443-1628-5.

Danijel Pavković, Joško Deur, Martin Janszand, and Nedjeljko Perić. Self-tuning Control of an Electronic Throttle. In Proc. of the IEEE Conference on Control Applications, pages 149-154, June 2003.

Danijel Pavković, Joško Deur, Martin Jansz, and Nedjeljko Perić. Adaptive control of automotive electronic throttle. Control Engineering Practice, 14(2): 121-136, 2006.

Dominique Petitjean, Luciano Bernardini, Chris Middlemass, S. M. Shahed, and Ronald G. Hurley. Advanced Gasoline Engine Turbocharging Technology for Fuel Economy Improvements. In SAE World Congr., Techn. Paper 2004-010988, March 2004.

K. J. Åström. Theory and applications of adaptive control - A survey. Automatica, 19(5):471-486, 1983. 
Edmond Richer and Yildirim Hurmuzulu. A High Performance Pneumatic Force Actuator System: Part I-Nonlinear Mathemathical Model. J. of Dynamic Systems, Measurement and Control, 122(3):416-425, June 1999.

R. Scattolini, C. Siviero, M. Mazzucco, S. Ricci, R. Poggio, and C. Rossi. Modeling and Identification of an Electromechanical Internal Combustion Engine Throttle Body. Control Engineering Practice, 5(9):1253-1259, 1997.

Spencer C. Sorenson, Elbert Hendricks, Sigurjon Magnusson, and Allan Bertelsen. Compact and Accurate Turbocharger Modelling for Engine Control. In $S A E$ World Congr., Techn. Paper 2005-01-1942, April 2005.

Richard Stone. Introduction to internal combistion engines. Palgrave Macmillan, 4th edition, 2012.

Hans-Martin Strieb and Hubert Bischof. Electronic Throttle Control (ETC): A Cost Effective System for improved Emissions, Fuel, and Driveability. In SAE World Congr., Techn. Paper 960338, February 1996.

Viktor Szente and János Vad. Computational and Experimental Investigation on Solenoid Valve Dynamics. In Proc. of the IEEE/ASME Int. Conference on Advanced Intelligent Mechatronics, volume 1, pages 618-623, July 2001.

Andreas Thomasson. Wastegate Actuator Modeling and Tuning of a PID Controller for Boost Pressure Control. Master's thesis, Linköping University, SE-581 83 Linköping, 2009.

Andreas Thomasson and Lars Eriksson. Model-Based Throttle Control using Static Compensators and IMC based PID-Design. In Proc. of the E-COSM, Paris, France, 2009.

Andreas Thomasson and Lars Eriksson. Modeling and Control of Co-Surge in Bi-Turbo Engines. In Proc. of the IFAC World Congr., Milano, Italy, 2011a.

Andreas Thomasson and Lars Eriksson. Model-Based Throttle Control using Static Compensators and Pole Placement. Oil \& Gas Science and Technology - Rev. IFP, 66(4):717-727, 2011b.

Andreas Thomasson and Lars Eriksson. Co-Surge Detection and Control for BiTurbo Engines with Experimental Evaluation. In Proc. of the IFAC Symposium on Advances in Automotive Control,, Tokyo, Japan, 2013.

Andreas Thomasson and Lars Eriksson. Co-Surge in Bi-Turbo Engines - Measurements, Analysis and Control. Submitted to Control Engineering Practice, 2014 .

Andreas Thomasson, Lars Eriksson, Oskar Leufvén, and Per Andersson. Wastegate Actuator Modeling and Model-Based Boost Pressure Control. In Proc. of the E-COSM, Paris, France, 2009. 
Andreas Thomasson, Lars Eriksson, Tobias Lindell, James Peyton Jones, Jill Spelina, and Jesse Frey. Tuning and experimental evaluation of a likelihoodbased engine knock controller. In Proc. of the IEEE Conference on Decision and Control, Florence, Italy, 2013a.

Andreas Thomasson, Oskar Leufvén, Ivan Criscuolo, and Lars Eriksson. Modeling and validation of a boost pressure actuation system, for a series sequentially turbocharged SI engine. Control Engineering Practice, 21(12):1860-1870, 2013b.

R. Tudor. Electronic Throttle Control as an Emission Reduction Device. In SAE World Congr., Techn. Paper 930939, March 1993.

R. B. van Varseveld and G. M. Bone. Accurate Position Contol of a Pneumatic Actuator Using On7Off Solenoid Valves. IEEE/ASME Trans. on Mechatronics, 2(3):195-204, 1997.

Charles B. Vance. Velocity of sound in tubes at audiable and ultrasonic frequencies. Physical Review, 39:737-744, February 1932.

M. Vašak, M. Baotić, M. Morari, I. Petrović, and N. Perić. Constrained optimal control of an electronic throttle. Int. J. of Control, 79(5):465-478, 2006.

Mario Vašak, Ivan Petrović, and Nedjeljko Perić. State Estimation of an Electronic Throttle Body. In IEEE Int. Conference on Industrial Technology, volume 1, pages 472-477, December 2003.

Mario Vašak, Mato Baotić, Ivan Petrović, and Nedjeljko Perić. Hybrid TheoryBased Time-Optimal Control of an Electronic Throttle. IEEE Trans. on Industrial Electronics, 54(3):1483-1494, 2007.

Jihong Wang, Junscheng $\mathrm{Pu}$, and Philip Moore. A practical control strategy for servo-pneumatic actuator systems. Control Engineering Practice, 12(12): 1483-1488, 1999.

N. Watson and M.S. Janota. Turbocharging the Internal Combustion Engine. The Macmillan Press ltd, 1982. ISBN 0-333-24290-4.

M.H. Westbrook and J.D. Turner. Automotive sensors. IOP Publishing, 1994.

Frank Willems and Bram de Jager. Modeling and Control of Compressor Flow Instabilities. Control Systems, 19, 1999.

Fulin Xiang and Jan Wikander. Block-oriented approximate feedback linearization for control of pneumatic actuator system. Control Engineering Practice, 12(4):387-399, April 2004.

G. Zito, P. Tona, and P. Lassami. "The Throttle Control Benchmark". In Proc. of the E-COSM, November 2009. 
Papers 




\section{Papers}

The articles associated with this thesis have been removed for copyright reasons. For more details about these see:

http://urn.kb.se/resolve?urn=urn:nbn:se:liu:diva-105687 
Linköping studies in science and technology. Dissertations.

Division of Vehicular Systems

Department of Electrical Engineering

Linköping University

No. 1 Magnus Pettersson Driveline Modeling and Control, 1997

No. 2 Lars Eriksson Spark Advance Modeling and Control, 1999

No. 3 Mattias Nyberg Model Based Fault Diagnosis: Methods, Theory, and Automotive Engine Applications, 1999

No. 4 Erik Frisk Residual Generation for Fault Diagnosis, 2001

No. 5 Per Andersson Air Charge Estimation in Turbocharged Spark Ignition Engines, 2005

No. 6 Mattias Krysander Design and Analysis of Diagnosis Systems Using Structural Methods, 2006

No. 7 Jonas Biteus Fault Isolation in Distributed Embedded Systems, 2007

No. 8 Ylva Nilsson Modelling for Fuel Optimal Control of a Variable Compression Engine, 2007

No. 9 Markus Klein Single-Zone Cylinder Pressure Modeling and Estimation for Heat Release Analysis of SI Engines, 2007

No. 10 Anders Fröberg Efficient Simulation and Optimal Control for Vehicle Propulsion, 2008

No. 11 Per Öberg A DAE Formulation for Multi-Zone Thermodynamic Models and its Application to CVCP Engines, 2009

No. 12 Johan Wahlström Control of EGR and VGT for Emission Control and Pumping Work Minimization in Diesel Engines, 2009

No. 13 Anna Pernestål Probabilistic Fault Diagnosis with Automotive Applications, 2009

No. 14 Erik Hellström Look-ahead Control of Heavy Vehicles, 2010

No. 15 Erik Höckerdal Model Error Compensation in ODE and DAE Estimators with Automotive Engine Applications, 2011

No. 16 Carl Svärd, Methods for Automated Design of Fault Detection and Isolation Systems with Automotive Applications, 2012.

No. 17 Oskar Leufvén, Modeling for control of centrifugal compressors, 2013.

No. 18 Christofer Sundström, Model Based Vehicle Level Diagnosis for Hybrid Electric Vehicles, 2014. 